\title{
HER2 EXPRESSION AS A PROGNOSTIC FACTOR IN METASTATIC GASTRIC CANCER
}

\author{
Pedro Nazareth AGUIAR JUNIOR ${ }^{1}$, Ricardo ARTIGIANI NETO ${ }^{2}$ and \\ Nora Manoukian FORONES ${ }^{3}$
}

Received 14/10/2015

Accepted 10/2/2016

\begin{abstract}
Background - Human epidermal growth factor receptor 2 (EGFR2/HER2/ErbB2) is a transmembrane receptor that stimulates cell proliferation when activated. The correlation of HER2 expression with prognosis has been studied in many cancer types. However, its relationship with survival of patients with metastatic gastric cancer remains unknown. Moreover, there is a lack of information on this issue in a Brazilian population. Objective - To assess the proportion of patients whose tumor cells express HER 2 and correlate this with clinical characteristics as well as treatment outcomes. Methods - This was a retrospective study. We included adult patients with metastatic gastric cancer treated at an University Hospital between 2011 and 2015 . Patients did not receive anti-HER2 therapy. Receptor expression was evaluated by immunohistochemistry. Survival risk factors were assessed individually with univariate Cox regression, and a $P$ value $<0.05$ was considered statistically significant. Results - Forty-nine patients were included in this study. However, only 32 had samples assessed for HER 2 expression. Five (16\%) patients were positive. Among HER2-negative patients, the average age was 54 years, $44 \%$ received a treatment protocol with three drugs, $70 \%$ had a performance status score $0-1$, and $41 \%$ had well or moderately differentiated histology. Among HER2-positive patients, the average age was 58 years, $40 \%$ received three drugs, $100 \%$ had a performance status score $0-1$, and $67 \%$ had well or moderately differentiated histology. Response rate was evaluated in 28 cases, and there was no difference between the groups (HER 2 -negative $52 \%$ vs. HER 2 -positive $40 \%$; $P=0.62$ ). Survival outcomes were numerically worse among HER2-positive patients. Median progression-free survival was 8.3 months for HER2-positive patients and 10.6 months for HER2-negative patients (HR 1.61, 95\% CI: 0.59-4.38); median overall survival was 14.8 months and 16.9 months for HER2-positive and HER2-negative patients, respectively (HR 1.52, 95\% CI: 0.50-4.66). Conclusion - HER2 overexpression in metastatic gastric cancer patients may be a predictor of poor prognosis and further validation is warranted. HEADINGS - Stomach neoplasms. Receptor ErbB2. Drug therapy. Molecular targeted therapy.
\end{abstract}

\section{INTRODUCTION}

Gastric cancer is the fifth most common neoplasm in $\mathrm{Brazil}^{(8)}$. More than 20 thousand new cases were expected yearly in 2014 and 2015 with 14 thousand deaths yearly ${ }^{(8)}$.

The concept that cancer is a syndrome and patients must share the same pathophysiological features has been changing in recent decades ${ }^{(6)}$. The discovery of new mutated targets followed by the development of specific molecular agents to bind them started a phase of treatment individualization and, as a result, improvement in clinical outcomes. One successful example of molecular targeted therapy is human epidermal growth factor receptor 2 (EGFR2/HER2/ ErbB2) ${ }^{(18)}$.

HER 2 is a tyrosine kinase transmembrane receptor expressed in a wide range of cancers, including gastric cancer. The extracellular domain has a site to bind growth factors, even though the receptor can activate itself when mutated. After activation, HER2 induces a receptor homo- or hetero-dimerization that initiates phosphorylation cascades in the intracellular domain. HER3 is another receptor of the EGFR fam- ily that does not have an extracellular binding domain; the most active dimer is HER2-HER3. Inside the cell, HER 2 elicits tyrosine kinase activity via phosphatidylinositol 3-kinase-AKT-mammalian target of rapamycin and Ras-Raf-ERK pathways ${ }^{(18)}$. These pathways lead to several reactions with potential to improve cancer and abbreviate patient survival such as cell survival, proliferation, inhibition of apoptosis as well as angiogenesis ${ }^{(18)}$.

HER 2 overexpression occurs in 7\%-22\% of gastric cancer cases ${ }^{(12)}$ and is more commonly associated with proximal (33\% in the gastroesophageal junction vs $20.9 \%$ in the stomach) and intestinal-type (32\% vs $6 \%$ ) tumors ${ }^{(1)}$. HER 2 overexpression in gastric cancer is evaluated by immunohistochemistry (IHC) in a specific way, different from methods used for other malignancies such as breast cancer ${ }^{(1)}$. For tumors with $2+$ by IHC, an amplification test (in situ hybridization [ISH]) must be performed to confirm the results. Similar to breast cancer, there is a high correlation between primary and metastasis HER2 status ${ }^{(21)}$.

Trastuzumab is a humanized recombinant monoclonal antibody that binds the extracellular subdomain IV of HER2. It inhibits cell proliferation and

Setor de Oncologia, Universidade Federal de São Paulo, SP, Brasil; 2 Departamento de Patologia, Universidade Federal de São Paulo, SP, Brasil; 3 Disciplina de Gastroenterologia, Universidade Federal de São Paulo, SP, Brasil.

Correspondence: Nora Manoukian Forones. Disciplina de Gastroenterologia (UNIFESP). Rua Botucatu, 740, $2^{\circ}$ andar - CEP: 04023-900 - São Paulo, SP - Brasil. E-mail: nmforones@unifesp.br 
activates apoptosis. Trastuzumab has been shown to substantially improve the survival of patients with metastatic gastric cancer compared to chemotherapy alone ${ }^{(1)}$. Unfortunately, it is not available in the Brazilian Public Health System for this indication.

Moreover, the implication of HER2 expression on prognosis remains undefined in patients with metastatic gastric cancer who do not receive trastuzumab. There are conflicting results in the literature and differences in IHC assessment across trials ${ }^{(3)}$; In addition, Brazilian data on this issue are scarce.

The objective of this study was to assess HER2 expression and its relationship with gastric cancer prognosis in a Brazilian population. Although there is no data regarding to disparities in HER2 expression in gastric cancer around the world, the largest data available is from eastern countries.

\section{METHODS}

\section{Patients}

This study included adult patients with a histologically confirmed diagnosis of adenocarcinoma of the stomach or esophagogastric junction and radiologic evidence of metastatic disease. All patients were treated in the Oncology Division of the Federal University of São Paulo (UNIFESP) from January 2011 to May 2015. Individuals must have received at least 1 cycle of chemotherapy to be eligible for this study. No patient had the tumor resected. Participants consented to the use of their tumor sample and personal information by signing the informed consent form.

\section{Study design}

This was a retrospective study with a quantitative approach. Patient electronic records were used to collect not only demographic and clinical data, but also features and outcomes of treatments. The study was conducted in accordance with resolution number 466/12 of the Brazilian Health Ministry and was approved by the institutional Ethics Committee.

\section{HER2 assessment}

We assessed HER 2 status by IHC using paraffinembedded tissue and a rabbit IgG antibody anti c-erbB-2/ HER-2 (named as SP3) produced by Spring Bioscience ${ }^{\circ}$. The antibody lot number is 12061 LVG. Its reactivity was tested only for human tumor cell; however, it is predicted by homology for dog, hamster, mouse and rat. We used a dilution 1:150 and the antigen retrieval was done in a $\mathrm{pH}$ 3.0. After this, the immunocoloration was performed in a Dako $^{\circ}$ Autostainer device. The positive and the negative control were standardized breast cancer sample. We used just one sample from each patient. An expert in gastrointestinal pathology selected the best sample and then evaluated the slide using the definitions established in the ToGA trial ${ }^{(1)}$.

According to this definition that became the standard worldwide, IHC staining can be scored from $0+$ (no reactivity or membranous reactivity in $<10 \%$ of tumor cells in surgical specimens or any tumor cell in biopsy specimens; Figure 1) to $3+$ (strong complete, basolateral, or lateral membranous reactivity in $\geq 10 \%$ of tumor cells in surgical specimens or strong complete reactivity in biopsy specimens; Figure 2). Inconclusive tests were repeated until a conclusive result was obtained. HER 2 was considered positive with a score of $3+$ and negative with a score of $0+$ or $1+$ (tumor cell cluster with faint or barely perceptible membranous reactivity, irrespective of the percentage of tumor cells stained by IHC in biopsy specimens). For tumors with $2+$ (tumor cell cluster with a weak to moderate complete, basolateral, or lateral membranous reactivity, irrespective of the percentage of tumor cells stained by IHC in biopsy specimens), an amplification test (ISH) was performed to confirm the results.

Patients with histological diagnosis outside UNIFESP were asked to bring their material to be reviewed in our institution.

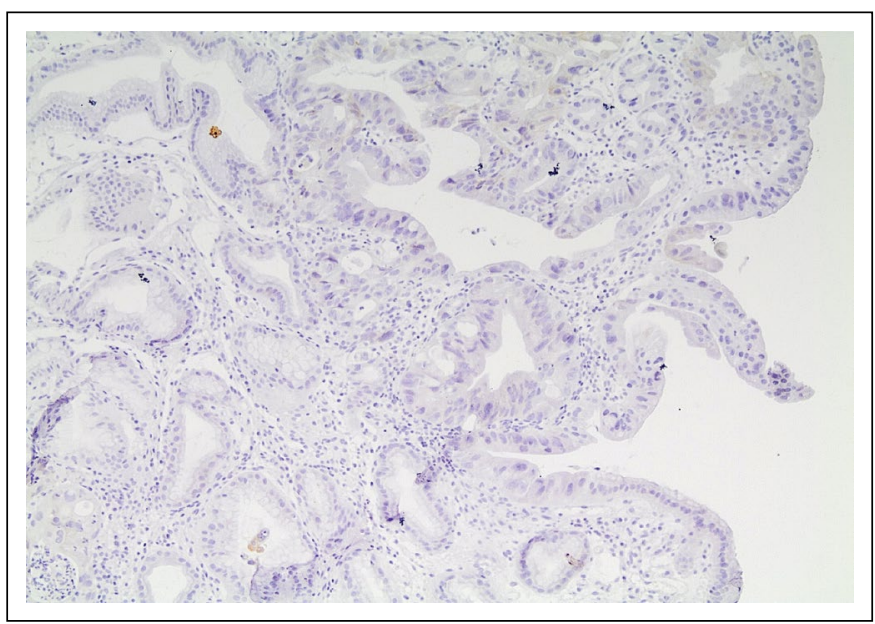

FIGURE 1. Microscopy of a HER2-negative tumor sample. 20X microscopy of an immunohistochemistry assay without HER2 expression on tumor cells surface.

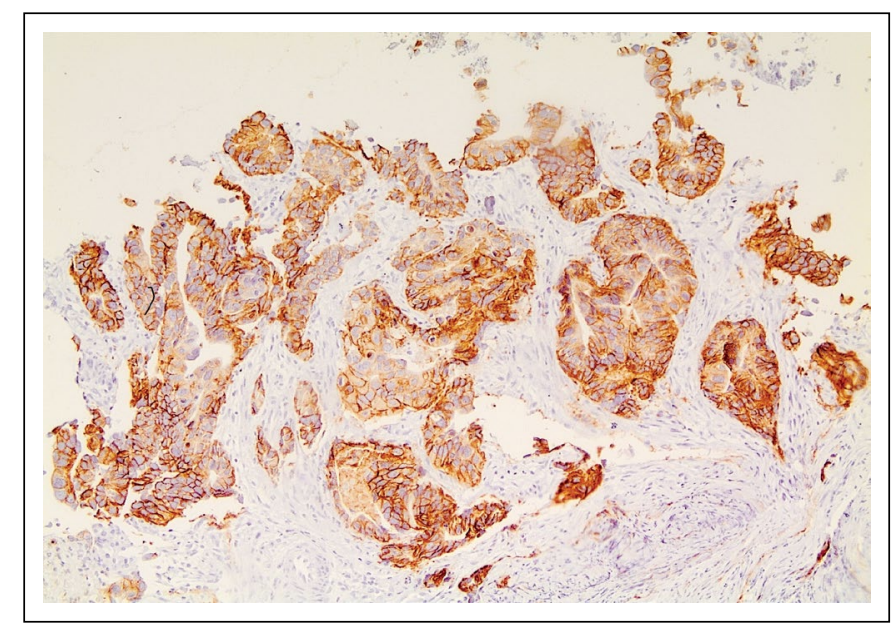

FIGURE 2. Microscopy of a HER2-positive tumor sample.

20X microscopy of an immunohistochemistry assay with a strong HER2 expression on tumor cells surface. 


\section{Treatment protocols}

The primary physician chose between a 3 drug regimen and a 2 drug regimen at the time of the clinic appointment based upon patient intrinsic factors and clinical characteristics. There is neither an institutional protocol nor an international guideline that define the best regimen. Patients did not receive anti-HER2 therapy because it is not available in the Brazilian Health System.

The protocol defined as " 3 drug" consisted of an intravenous bolus of $50 \mathrm{mg} / \mathrm{m}^{2}$ epirubicin and $130 \mathrm{mg} / \mathrm{m}^{2}$ oxaliplatin every 3 weeks, combined with $625 \mathrm{mg} / \mathrm{m}^{2}$ capecitabine twice daily, administered continuously (this protocol is also known as EOX).

In this study, the protocol described as " 2 drugs" grouped different chemotherapy protocols, based on combinations of platinum agents and fluoropyrimidines. The preferred and predominant regimen, XELOX, consisted of $130 \mathrm{mg} / \mathrm{m}^{2}$ oxaliplatin on the first day of the cycle, followed by $1000 \mathrm{mg} / \mathrm{m}^{2}$ capecitabine twice daily for 14 days, every 3 weeks. In the event that capecitabine was not available, the regimen was modified to Nordic-FLOX that consisted of $85 \mathrm{mg} / \mathrm{m}^{2}$ oxaliplatin on the first day, followed by a bolus of $500 \mathrm{mg} / \mathrm{m}^{2} 5$-fluorouracil (5-FU) and $60 \mathrm{mg} / \mathrm{m}^{2}$ folinic acid for the first 2 days of the cycle, every 2 weeks.

All regimens were repeated until the first radiologic evidence of disease progression or unacceptable adverse event.

\section{Efficacy and safety}

The primary endpoint of this study was median overall survival (mOS), defined as the time, in months, from diagnosis to death from any cause. Secondary endpoints were median progression-free survival (mPFS) and response rate (RR). PFS was defined as the time, in months, between the first day of treatment and the first radiologic documentation of disease progression or death from any cause, whichever occurred first ${ }^{(5)}$.

Patients underwent imaging tests every 2-3 months according to international guidelines. UNIFESP's radiology team assessed all images according to the Response Evaluation Criteria in Solid Tumors version 1.1 ${ }^{(19)}$. The scans were not re-evaluated by any external team.

Physicians saw the patients and checked blood analysis before each cycle. All adverse events were graded in accordance with the Common Terminology Criteria for Adverse Events version 4 of the National Cancer Institute ${ }^{(9)}$. Dose reductions and third agent suppression occurred when necessary.

The performance status of the patients (0-5) was determined according to the criteria proposed by the Eastern Cooperative Oncology Group ${ }^{(16)}$.

\section{Statistical analysis}

Patients' demographic characteristics were assessed by descriptive statistics. Regression tests were not performed because of the small population of the study.
Progression-free Survival and Overall Survival were evaluated using the Kaplan-Meier method. Univariate Cox regression analysis was performed to assess HER2 expression as prognostic factor ${ }^{(4)}$. Other prognostic factors were assessed individually and were not stratified by receptor status because of the limited number of individuals.

The response rate in each HER2 group (HER2-positive and HER2-negative groups) was compared using Pearson's chi-square test. We considered differences statistically significant when $P$ was $<0.05$.

The proportion of tumors with HER2 expression is estimated in $20 \%$ based on the available literature on this subject. The ideal sample size to demonstrate a difference of $20 \%$ in Overall Survival with an $80 \%$ of power and with an alpha error of $5 \%$ is 2,801 individuals.

\section{RESULTS}

\section{Patients}

Forty-nine patients were eligible for inclusion; however, only 32 were assessed for HER 2 status. Six patients had biopsies performed at other institutions and did not bring their materials to UNIFESP for evaluation. Eight patients did not have enough material for HER2 evaluation, and in another three cases, the samples were not available. Five $(16 \%)$ patients were HER2-positive; all of their samples had IHC scores of $3+$. There were no cases with IHC scores of $2+$. In general, the groups were comparable in terms of demographic characteristics. Among patients with HER2-positive tumor the average age was 58 years (ranging from 42 to 88$), 4(80 \%)$ patients were male, $3(60 \%)$ individuals were from the North or Northeast regions of Brazil and the same proportion was Caucasian. Smoking and alcoholism were both observed in $60 \%$ of participants. Regarding to the population with HER2-negative tumors the average age was 54 years (ranging from 24 to 80 ), 17 (63\%) patients were male, $16(59 \%)$ individuals were from the South or Southeast regions of Brazil and $23(85 \%)$ were caucasian. Smoking was observed in $59 \%$ of the patients instead of alcoholism that was observed in about one third of the participants. Otherwise, there were some clinical disparities between the groups. None of the HER2positive tumors were diffuse-type, while $44 \%$ of the HER2-negative tumors were diffuse. The HER2-positive group also had more metastatic sites at diagnosis compared with the HER2-negative group ( $60 \%$ vs $26 \%$ of patients with 2 or more metastatic sites, respectively). Curiously, all HER2-positive patients had $>10 \%$ loss in body weight over the last 6 months before the diagnosis while $70 \%$ of HER2-negative patients had $>10 \%$ loss in body weight in the same period. Moreover, all HER2-positive tumors arose from the second and the third portion of the stomach instead of HER2-negative tumors where one third arose from the first third of the organ. Table 1 summarizes patients' characteristics by HER 2 status. 
TABLE 1: Baseline clinical and demographic characteristics according to HER 2 status

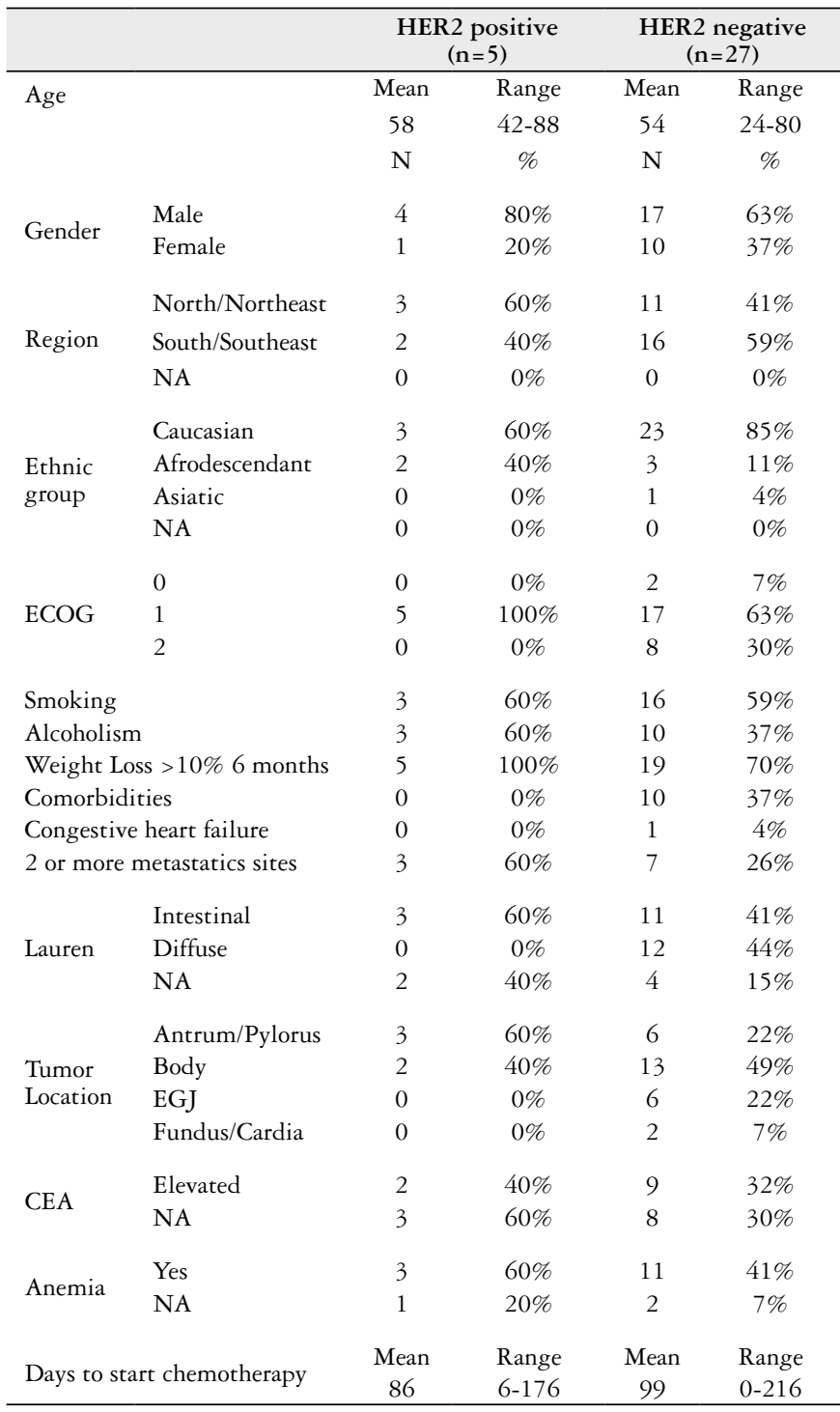

n: number; NA: not available; ECOG: performance was evaluated according to guidelines of the Eastern Cooperative Oncology Group, with a score of 0 indicating normal performance status, 1 mildly symptomatic, 2 symptomatic but in bed less than half the day, 3 symptomatic and in bed more than half the day, and 4 in bed the whole day; EGJ: esophagogastric junction; CEA: carcinoembryonic antigen.

\section{Clinical outcomes}

Twenty-eight cases were assessed for response, and there was no difference between HER2-positive and HER2-negative patients, with RRs of $40 \%$ and $52 \%$, respectively $(P=0.62$; Table 2). Nevertheless, survival seemed to be worse among HER2-positive patients. These differences were not statistically significant. The mPFS durations for HER2-negative and HER2-positive patients were 10.6 months and 8.3 months, respectively (HR 1.61, 95\% CI: $0.59-4.38$; Figure 3), and the mOS durations were 16.9 months and 14.8 months, respectively (HR 1.52, 95\% CI: 0.50-4.66; Figure 4).
TABLE 2. Treatment characteristics and response rate

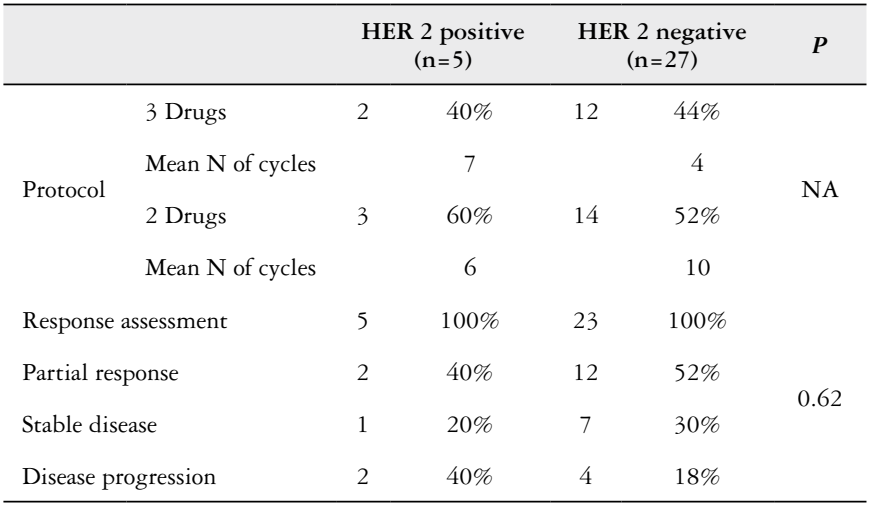

n: Number; NA: not available.

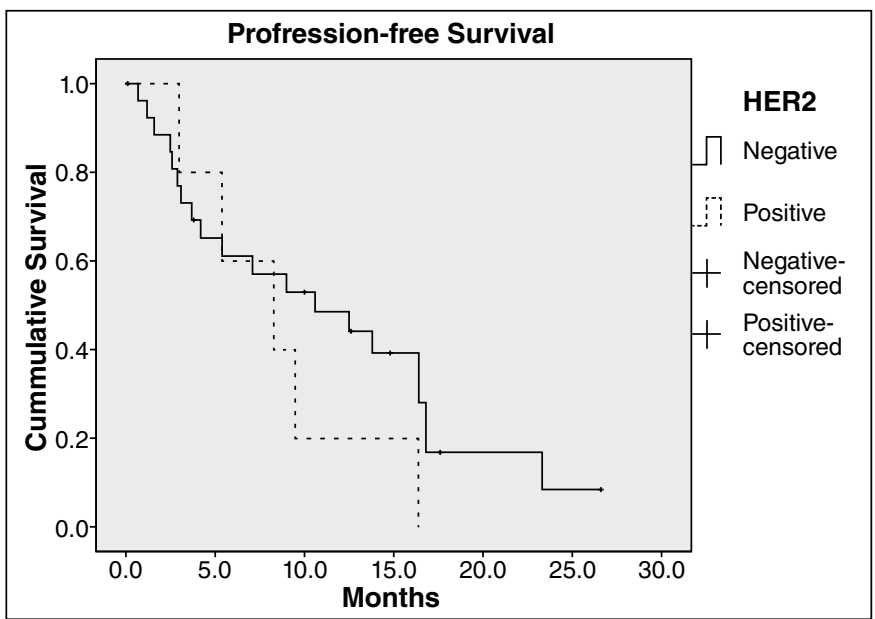

FIGURE 3. Progression-free survival according to HER 2 status.

Median Progression-Free Survival: HER2-positive tumors: 8.3 months; HER2-negative tumors: 10.6 monts; (HR 1.61, 95\% CI: 0.59-4.38).

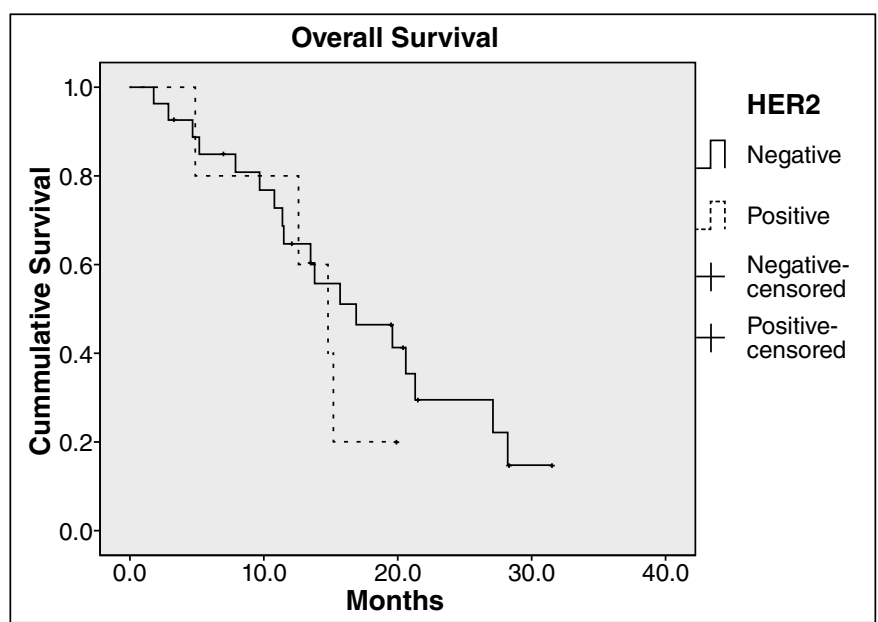

FIGURE 4. Overall survival according to HER 2 status.

Median Overall Survival: HER2-positive tumors: 14.8 months; HER-2 negative tumors: 16.9 months. (HR 1.52, 95\% CI: 0.50-4.66). 


\section{DISCUSSION}

The prognosis of metastatic gastric cancer remains poor, although chemotherapy has improved survival substantially ${ }^{(14)}$; regardless of chemotherapy regimen, mOS seems to be limited to around 12 months $^{(20)}$. In the ToGA trial, trastuzumab resulted in a significant improvement in overall survival, with mOS extending beyond 1 year $^{(1)}$. However, the implications of HER 2 expression on prognosis in patients with metastatic disease who were not treated with anti-HER2 agents remain unclear.

The prevalence of HER 2 overexpression in gastric cancer is variable. In the ToGA trial, 3,665 patients were screened, and $810(22 \%)$ were HER2-positive ${ }^{(1)}$. This proportion is similar to that observed for breast cancer, but higher than that observed in our study $(16 \%)$. In a systematic review that included 49 studies and 11,337 patients, the prevalence of HER 2 overexpression was $18 \%{ }^{(3)}$. However, only one study included in this systematic review assessed HER2 status using the same criteria as the ToGA trial, and some trials included non-metastatic patients. In Brazil, two studies have assessed HER 2 overexpression, but only among patients who do not have metastatic disease, and they used a different criteria instead of ToGA criteria ${ }^{(7)}$. Jácome et al. evaluated 201 patients and found $17 \%$ of cases had HER 2 overexpression ${ }^{(11)}$, while Begnami et al. evaluated 221 individuals and found $12 \%$ of cases had HER2 positivity ${ }^{(2)}$.

The implications of HER 2 expression on prognosis are more controversial. In the systematic review, two $(6 \%)$ studies reported significantly longer survival in patients with HER2 overexpression, while $13(37 \%)$ studies reported the opposite finding. As a result, receptor positivity seems to be related to poor prognosis: mOS of 21 months versus 33 months and 5 -year survival rate of $42 \%$ versus $52 \%{ }^{(3)}$. Again, this review has a limitation because it included several trials that did not assessed HER 2 expression by ToGA criteria. Although the prognostic impact of HER 2 status was not formally assessed in the ToGA trial, interestingly, the mOS of patients in the control arm appeared to increase as HER2 protein expression levels increased (median survival durations were 7.2, 10.2, 10.8, and 12.3 months for those with IHC 0/FISH +, IHC $1+/$ FISH +, IHC $2+/$ FISH +, and IHC $3+/$ FISH+ tumors, respectively $)^{(1)}$.

Moreover, retrospective evaluations performed in recent trials using the same assessment criteria as those used in the
ToGA trial showed similar results. In a European and USA International collaborative analysis that included 381 patients with metastatic disease, HER2-positive patients $(20 \%)$ had a favorable prognosis compared with HER2-negative patients (mOS 13.9 vs 11.4 months; $P=0.047$; non-statistically significant after multivariate analysis) ${ }^{(10)}$. The EXPAND trial compared chemotherapy with or without cetuximab. In a retrospective analysis, it described a non-statistically significant favorable prognosis in both arms for patients with HER 2 expression (mOS in control arm: 14.0 vs 9.7 months; mOS in treatment arm: 13.3 vs. 9.2 months) ${ }^{(13)}$. In contrast, the retrospective assessment of HER2 in the AVAGAST trial and REAL 3 trial did not show a relationship between receptor overexpression and prognosis ${ }^{(15,17)}$.

In Brazil, Begnami et al. found that patients with HER2 overexpression had short OS (mOS 17 vs 40 months; $P=0.023)^{(2)}$. In contrast, Jácome et al. performed a multivariate analysis and concluded that receptor expression should not be considered a poor prognostic factor ${ }^{(11)}$. Once again, it is important to take into consideration that these studies included only patients with resected tumors and HER2 expression was assessed not using the ToGA Trial criteria ${ }^{(7)}$.

Our study also has certain limitations, such as its retrospective design and small sample size. The estimated sample size to confirm our findings should be at least 87 times larger than the population included in this study. Nevertheless, we still consider our findings important as we have provided results specific to a Brazilian population with metastatic gastric cancer. These findings need further validation in order to help regulatory agencies make decisions regarding antiHER2 treatment availability in the Brazilian Public Health System and preview the costs of this policy.

\section{CONCLUSION}

HER 2 overexpression in metastatic gastric cancer patients may be a predictor of poor prognosis and further validation is warranted.

\section{Authors' contributions}

Aguiar Junior PN: data collection, statistical analysis and writing of text. Artigiani Neto R: HER2 assay execution. Forones NM: study design, treatment supervision and critical analysis. 
Aguiar Junior PN, Artigiani Neto R, Forones NM. A expressão de HER2 como fator prognóstico no câncer gástrico metastático. Arq Gastroenterol. 2016,53(2): 62-7.

RESUMO - Contexto - O receptor 2 do fator de crescimento epidermal humano (EGFR2/HER2/ErbB2) é um receptor transmembrana que estimula a proliferação celular quando ativado. A expressão de HER2 foi estudada em diversas neoplasias, como câncer gástrico. No entanto, sua relação com a sobrevida dos pacientes com câncer gástrico metastático permanece desconhecida. Além disso, há falta de informação sobre este assunto na população brasileira. Objetivo - Avaliar a proporção de pacientes cujas células tumorais expressam HER2 e correlacionar essa característica com aspectos clínicos e também com os desfechos do tratamento. Métodos - Este é um estudo retrospectivo. Foram incluídos pacientes adultos com câncer gástrico metastático tratados em um Hospital Geral Universitário entre 2011 e 2015. Nenhum paciente recebeu terapia anti-HER2. A expressão do receptor foi avaliada por imuno-histoquímica. Fatores de risco para a sobrevida foram avaliados com regressão de Cox univariada e valor $P<0,05$ foi considerado estatisticamente significativo. Resultados - Quarenta e nove pacientes foram incluídos neste estudo. No entanto, 32 tiveram amostras avaliadas para expressão de HER2. Cinco (16\%) pacientes foram positivos. Entre os pacientes HER2 negativos: a idade média foi de 54 anos, $44 \%$ receberam um protocolo com três drogas, 70\% apresentavam um score de status performance $0-1$, $41 \%$ tinham histologia bem ou moderada diferenciada. Entre os pacientes HER2 positivos: a média de idade foi de 58 anos, 40\% receberam três drogas, $100 \%$ apresentavam um score de status performance de $0-1,67 \%$ tinham histologia bem ou moderada diferenciada. A taxa de resposta foi avaliada em 28 casos e não houve diferença entre os grupos (HER2 negativo 52\% e HER2 positivo de 40\%; $P=0,62$ ). A sobrevida foi menor entre pacientes HER2 positivos. As medianas de Sobrevida Livre de Progressão foram 8,3 meses e 10,6 meses, respectivamente (HR 1,61; IC 95\%: 0,59-4,38). As medianas de Sobrevida Global foram 14,8 meses e 16,9 meses, respectivamente (HR 1,52; IC 95\%: 0,50-4,66). Conclusão - A expressão tumoral de HER2 pode ser um fator de pior prognóstico para pacientes portadores de câncer gástrico metastático e uma validação futura desses achados se faz necessária.

DESCRITORES - Neoplasia gástricas. Receptor ErbB2. Quimioterapia. Terapia de alvo molecular.

\section{REFERENCES}

1. Bang YJ, Van Cutsem E, Feyereislova A, Chung HC, Shen L, Sawaki A, et al. Trastuzumab in combination with chemotherapy versus chemotherapy alone for treatment of HER2-positive advanced gastric or gastro-oesophageal junction cancer (ToGA): a phase 3, open-label, randomised controlled trial. Lancet. 2010;376:687-97.

2. Begnami MD, Fukuda E, Fregnani JH, Nonogaki S, Montagnini AL, da Costa WL, Soares FA. Prognostic implications of altered human epidermal growth factor receptors (HERs) in gastric carcinomas: HER2 and HER3 are predictors of poor outcome. J Clin Oncol. 2011;29:3030-6.

3. Chua TC, Merrett ND. Clinicopathologic factors associated with HER2-positive gastric cancer and its impact on survival outcomes--a systematic review. Int J Cancer. 2012;130:2845-56.

4. Cox D, Oakes D. Analysis of survival data. New York: Chapman and Hall, 1990.

5. Green S, Crowley J. Clinical trials in oncology. London: Chapman \& Hall, 1997.

6. Hanahan D, Weinberg RA. Hallmarks of cancer: the next generation. Cell. 2011;144:646-74

7. Hofmann M, Stoss O, Shi D, Büttner R, van de Vijver M, Kim W, et al. Assessment of a HER2 scoring system for gastric cancer: results from a validation study. Histopathology. 2008;52:797-805.

8. INCA. Estimativas para o ano de 2014 das taxas brutas de incidência por 100 mil habitantes e do número de casos novos de câncer, segundo sexo e localização primária. 2014

9. Institute NC. Common Terminology Criteria for Adverse Events. [Internet]. [cited August, 2014]. Available from: http://ctep.cancer.gov/protocolDevelopment/electronic_applications/ctc.htm

10. Janjigian YY, Werner D, Pauligk C, Steinmetz K, Kelsen DP, Jäger E, et al. Prognosis of metastatic gastric and gastroesophageal junction cancer by HER2 status: a European and USA International collaborative analysis. Ann Oncol. 2012;23:2656-62.

11. Jácome AA, Wohnrath DR, Scapulatempo Neto C, Carneseca EC, Serrano SV, Viana LS, et al. Prognostic value of epidermal growth factor receptors in gastric cancer: a survival analysis by Weibull model incorporating long-term survivors. Gastric Cancer. 2014; 17:76-86.

12. Lieto E, Ferraraccio F, Orditura M, Castellano P, Mura AL, Pinto M, et al. Expression of vascular endothelial growth factor (VEGF) and epidermal growth factor receptor (EGFR) is an independent prognostic indicator of worse outcome in gastric cancer patients. Ann Surg Oncol. 2008;15:69-79.
13. Lordick F, Kang YK, Chung HC, Salman P, Oh SC, Bodoky G, et al. Capecitabine and cisplatin with or without cetuximab for patients with previously untreated advanced gastric cancer (EXPAND): a randomised, open-label phase 3 trial. Lancet Oncol. 2013;14:490-9.

14. Murad AM, Santiago FF, Petroianu A, Rocha PR, Rodrigues MA, Rausch M. Modified therapy with 5-fluorouracil, doxorubicin, and methotrexate in advanced gastric cancer. Cancer. 1993;72:37-41.

15. Ohtsu A, Shah MA, Van Cutsem E, Rha SY, Sawaki A, Park SR, et al. Bevacizumab in combination with chemotherapy as first-line therapy in advanced gastric cancer: a randomized, double-blind, placebo-controlled phase III study. J Clin Oncol. 2011;29:3968-76.

16. Oken MM, Creech RH, Tormey DC, Horton J, Davis TE, McFadden ET, Carbone PP. Toxicity and response criteria of the Eastern Cooperative Oncology Group. Am J Clin Oncol. 1982;5:649-55.

17. Okines AF, Ashley SE, Cunningham D, Oates J, Turner A, Webb J, et al. Epirubicin, oxaliplatin, and capecitabine with or without panitumumab for advanced esophagogastric cancer: dose-finding study for the prospective multicenter, randomized, phase II/III REAL-3 trial. J Clin Oncol. 2010;28:3945-50.

18. Slamon DJ, Leyland-Jones B, Shak S, Fuchs H, Paton V, Bajamonde A, et al. Use of chemotherapy plus a monoclonal antibody against HER2 for metastatic breast cancer that overexpresses HER2. N Engl J Med. 2001;344:783-92.

19. Therasse P, Arbuck SG, Eisenhauer EA, Wanders J, Kaplan RS, Rubinstein $\mathrm{L}$, et al. New guidelines to evaluate the response to treatment in solid tumors. European Organization for Research and Treatment of Cancer, National Cancer Institute of the United States, National Cancer Institute of Canada. J Natl Cancer Inst. 2000;92:205-16.

20. Wagner AD, Unverzagt S, Grothe W, Kleber G, Grothey A, Haerting J, Fleig WE. Chemotherapy for advanced gastric cancer. Cochrane Database Syst Rev. 2010;17:CD004064.

21. Watson S, Validire P, Cervera P, Zorkani N, Scriva A, Lemay F, et al. Combined HER 2 analysis of biopsies and surgical specimens to optimize detection of trastuzumab-eligible patients in eso-gastric adenocarcinoma: a GERCOR study. Ann Oncol. 24:3035-9. 